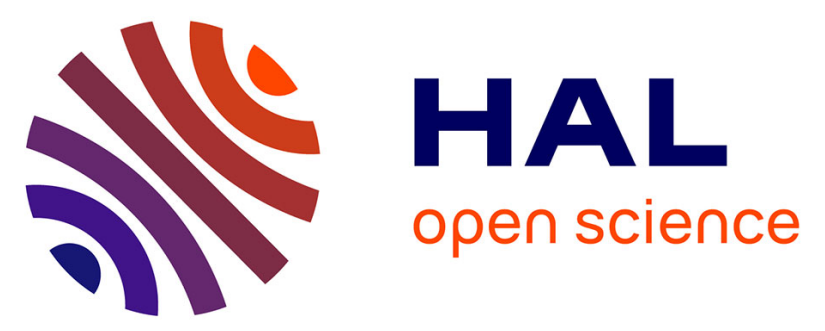

\title{
Possible Quaternary growth of a hidden anticline at the front of the Jura fold-and-thrust belt: geomorphological constraints from the Forêt de Chaux area, France
} Stéphane Molliex, Olivier Fabbri, Vincent Bichet, Herfried Madritsch

\section{- To cite this version:}

Stéphane Molliex, Olivier Fabbri, Vincent Bichet, Herfried Madritsch. Possible Quaternary growth of a hidden anticline at the front of the Jura fold-and-thrust belt: geomorphological constraints from the Forêt de Chaux area, France. Bulletin de la Société Géologique de France, 2011, 182 (4), pp.337-346. 10.2113/gssgfbull.182.4.337 . insu-00633369

\section{HAL Id: insu-00633369 \\ https://hal-insu.archives-ouvertes.fr/insu-00633369}

Submitted on 24 Nov 2011

HAL is a multi-disciplinary open access archive for the deposit and dissemination of scientific research documents, whether they are published or not. The documents may come from teaching and research institutions in France or abroad, or from public or private research centers.
L'archive ouverte pluridisciplinaire $\mathbf{H A L}$, est destinée au dépôt et à la diffusion de documents scientifiques de niveau recherche, publiés ou non, émanant des établissements d'enseignement et de recherche français ou étrangers, des laboratoires publics ou privés. 


\title{
Possible Quaternary growth of a hidden anticline at the front of the Jura fold-and-thrust belt: Geomorphological constraints from the Forêt de Chaux area, France.
}

\author{
Stéphane Molliex (1, 2), Olivier Fabbri (3), Vincent Bichet (3), Herfried Madritsch (4, 5)
}

(1) CEREGE, UMR 6635, Aix-Marseille Université, BP80, Europôle de l'Arbois, F-13545 Aix-en-Provence cedex, France

(2) Now at: UMR 6538 Domaines océaniques, Institut Universitaire Européen de la Mer,

Place Nicolas Copernic F-29280 Plouzané, France. E-mail: smolliex@ gmail.com

(3) UMR 6249 Chrono-environnement, Université de Franche-Comté, 16 route de Gray, F-25030 Besançon cedex, France

(4) Geological-Paleontological Institute Universtät Basel, Bernoullistr. 32, 4056 Basel, Switzerland.

(5) Now at: NAGRA, Hardstrasse 73, 5430 Wettingen, Switzerland

Key words: Jura fold-and-thrust belt, active tectonics, active folding, seismic hazard

Published in 2011 in Bulletin de la Société Géologique de France, 182, p. 337-346,

doi:10.2113/gssgfbull. 182.4.337

\begin{abstract}
This study presents new constraints for Plio-Quaternary (post-2.4 Ma to present-day) anticline growth along the frontal zone of the Jura fold-and-thrust belt, in the Forêt de Chaux area, located 30 $\mathrm{km} \mathrm{SW}$ of Besançon. The Forêt de Chaux area consists of a N80 E-elongated depression bordered by the Doubs and Loue rivers to the north and south respectively, and filled with Sundgau-type Pliocene alluvial deposits. The upper surface of the Pliocene deposits between the Loue and Doubs rivers is marked by a $\mathrm{N} 65^{\circ} \mathrm{E}$-trending ridge crossing the depression in a median position. A differential uplift along this ridge, post-dating the deposition of the gravels (2.4 Ma), is suggested by several geomorphological observations such as the opposite river migration on each side of the ridge as well as variations of drainage geometry and incision intensity. Geological and geophysical subsurface data indicate that the ridge roughly coincides with the axis of an anticline hidden beneath the Pliocene deposits. The observed uplift is presumably related to a post- $2.4 \mathrm{Ma}$ anticline growth. The fact that the azimuth of the hidden anticline axis is parallel to the strike of deep-seated Late Paleozoic basement faults and not to the local strike of the thin-skinned Jura structures indicates that the inferred post-Pliocene deformation could possibly be an expression of a recent thick-skinned deformation of the basement of the northern Alpine foreland. The focal depth $(15 \mathrm{~km})$ of the February $24^{\text {th }}, 2004$, Besançon earthquake supports the hypothesis of a basement fault reactivation.
\end{abstract}

Propagation possible d'un anticlinal masqué au front de la chaîne plissée du Jura au Quaternaire : indices géomorphologiques dans le secteur de la forêt de Chaux, France.

Mots clés: chaîne plissée, Jura, tectonique active, plissement actif, risque sismique

\section{Résumé}

Cette étude présente de nouveaux indices en faveur d'une croissance, au cours du Plio-Quaternaire (post-2.4 Ma), d'un anticlinal situé au front de la chaîne du Jura, dans le secteur de la Forêt de Chaux à $30 \mathrm{~km}$ au sud-ouest de Besançon. La Forêt de Chaux correspond à une dépression allongée orientée $\mathrm{N} 80^{\circ} \mathrm{E}$ et comblée par des dépôts alluviaux pliocènes de type Sundgau. Cette dépression est bordée au nord par le Doubs et au sud par la Loue. Le secteur situé entre ces deux rivières est marqué par la présence d'une ride orientée $\mathrm{N} 65^{\circ} \mathrm{E}$, qui traverse la forêt de Chaux d'est en ouest. 
Un soulèvement régional plus récent que $2.4 \mathrm{Ma}$ le long de cette ride $\mathrm{N} 65^{\circ} \mathrm{E}$ est suggérée par plusieurs indices géomorphologiques comme les variations de la géométrie du réseau de drainage, les différences de degré d'incision ou les migrations de rivières de part et d'autre de la ride $\mathrm{N} 65^{\circ} \mathrm{E}$. Des données de géophysique et de forages montrent que cette ride se superpose à l'axe d'un anticlinal masqué sous les dépôts alluviaux. Le soulèvement décelé semble donc résulter de la croissance post-2.4 Ma d'un anticlinal. L'azimuth de l'axe de l'anticlinal masqué est oblique aux directions locales des plis et des failles affectant la couverture et, au contraire, est parallèle à la direction des failles du socle anté-triasique connues dans le secteur d'étude ou à proximité, ce qui plaide en faveur d'une réactivation d'une faille du socle paléozoïque de l'avant-pays alpin. La profondeur focale $(15 \mathrm{~km})$ du séisme de Besançon du 24 février 2004 plaide également en faveur de cette hypothèse.

\section{Introduction}

Active deformation in the Alps is the consequence of the convergence between the African and European plates which, at the longitude of the Western Alps $\left(8^{\circ} \mathrm{E}\right)$, is taking place at a rate of $6,2 \pm$ $0,5 \mathrm{~mm} \cdot \mathrm{yr}^{-1}$ in a NNW-SSE direction [DeMets et al., 1990]. Less than half (2 3 mm.yr $\left.{ }^{-1}\right)$ of this deformation is accommodated across the Western Alps, the remaining being distributed in the Western Mediterranean domain [Calais, 1999; Calais et al., 2000]. A consequence of these low strain rates is that active structures such as faults or folds are difficult to identify. Neither can seismicity be helpful, given the scarcity of instrumentally detected events as well as of historical earthquakes. Conversely, the analysis of the spatial migration of streams through time is a powerful tool to decipher recent tectonic movements [e.g., Jackson et al., 1996; Schumm et al., 2000; Formento-Trigilio et al., 2002].

This geomorphological approach is particularly helpful in weakly active regions such as the foreland of Alpine domain. Particularly in the northern Alpine foreland it has been applied successfully and brought evidence for Post-Pliocene deformation along the outermost part of the Jura fold-and-thrust belt where it intersects with the European Cenozoic Rift system. Thereby most of the previous case studies focused on the area of the southern Upper Rhine Graben [Meyer et al., 1994; Nivière \& Winter, 2000; Giamboni et al., 2004a, b and c; Ustaszewski \& Schmid, 2007] and the central part of the Rhine Bresse Transfer Zone [Dreyfuss \& Glangeaud, 1950; Campy \& Contini, 1981; Campy, 1984; Madritsch et al., 2010a and b]. The aim of this contribution is to provide additional geomorphological evidence for Plio-Quaternary tectonic deformation from the transition zone between the Jura fold-and-thrust belt and the northern end of the Bresse Graben. The results are interpreted with respect to the regional structural setting, contribute to a better characterization of the present-day tectonic scenario and have implications on the seismic hazard assessment of the area.

\section{Geological outline}

The study area is located at the junction between the northern end of the Eocene-Oligocene Bresse Graben and the Miocene-Pliocene Jura fold-and-thrust belt (Fig. 1). It consists of a flat-lying depression, the Forêt de Chaux, considered as a branch of the Bresse Graben. In this area, the Jurassic bedrock is unconformably covered by Pliocene alluvial or lacustrine deposits loosely termed hereafter Forêt de Chaux deposits. From top to bottom, they include [Bonvalot, 1974; Chauve et al., 1979]: (1) the upper clay (argiles supérieures) complex, (2) the upper gravel (cailloutis supérieurs) complex, (3) the Etrepigney clay (argiles d'Etrepigney) complex, and (4) the lower gravel (cailloutis inférieurs) complex. The thickness of the Forêt de Chaux deposits is comprised between 35 and $100 \mathrm{~m}$. The thickness of each of the three uppermost complexes is changeable and is generally comprised between 0 and $10 \mathrm{~m}$. The thickness of the lower gravel complex, also changeable, is comprised between 25 and $90 \mathrm{~m}$. The age of deposition of the lower gravel complex is 4.2-2.9 Ma [Chaline, 1984; Puisségur, 1984; Farjanel, 1985; Petit et al., 1996] to 
4.2-2.6 Ma [Fejfar et al., 1998]. The age of deposition of the Etrepigney clay complex is estimated at 2.6-2.4 Ma.

The lower gravel complex displays strong similarities with the Sundgau deposits found further east, between Montbéliard and Basel (Fig. 1), in the southern end of the Rhine graben. The gravel deposits of both the Forêt de Chaux and the Sundgau areas are of the same petrographical nature and share a common Alpine origin indicated notably by reworked radiolarites. These deposits were transported by an ancestor of the Rhine river which was flowing from the Alps to the Sundgau and the Forêt de Chaux along the N60 ${ }^{\circ}$ E-trending present-day Doubs valley [Liniger, 1967; Bonvalot, 1974; Chauve et al., 1979; Petit et al., 1996; Madritsch et al., 2010a]. This ancestor is often referred to as the Paleo-Aar-Doubs river. To the southwest, gravels of the Forêt de Chaux area show a lateral change to the lacustrine deposits of the Bresse Graben. In the Doubs and Loue valleys, they are covered by Holocene alluvial deposits.

This study aims at examining the so far poorly investigated Forêt de Chaux area for signs of recent tectonic deformation that have recently been reported from neighboring areas (Nivière \& Winter 2000, Giamboni et al., 2004; Madritsch et al., 2010b). Unfortunately, bad outcrop conditions hinder a field-based geological analysis of the Forêt de Chaux deposits. Many of the geological boundaries reported in published geological maps [Kerrien et al., 1979] are only poorly constrained. Under these conditions, the interpretation of the Pliocene gravels as a deformation marker horizon is critical. In order to overcome this problem we apply geomorphological and geophysical methods. Geological logs of exploration core-drills as well as gravity and seismic reflection data were reinterpreted in order to better characterize the subsurface geology of the area. In addition, topographic maps (1/25 000 scale), aerial photographs and digital elevations models (50 mresolution DEM) were used to perform morphological and hydrographical analyses.

\section{Subsurface evidence for an anticline underneath the Forêt de Chaux}

Geophysical and geological data compiled during this study provide evidence for an anticline hidden underneath the Pliocene gravels of the Forêt de Chaux.

\subsection{Gravity data.}

Figure 2 shows a Bouguer anomaly map of the Forêt de Chaux area based on gravity data from more than 1000 stations of the French Gravity Database CGF 65 and RGF 83 networks [Grandjean et al., 1998; downloadable at http://infoterre.brgm.fr/]. Figure 2A shows the total Bouguer anomaly computed with a mean crustal rock density of 2.3. It reflects the gravity variations due to density variations within the earth crust [e.g., Ervin, 1977]. The anomaly values are negative and comprised between -31 and -4 mgal, indicating a rather deep Moho. Values decrease towards the SE, that is towards the Alpine range [Debrand-Passard et al., 1984; Chateauneuf \& Farjanel, 1989]. The total Bouguer anomaly is strongly influenced by the Moho geometry. In order to emphasize shallower gravity disturbances, it is possible to remove this first-order signal by extrapolating a trending surface which represents the regional tendency of the data. Figure 2B shows the distribution of the first-order Bouguer anomalies. It is obtained by extrapolating a third-degree trending surface minimizing the standard deviation with the surface representing the total Bouguer anomaly. Values are comprised between -28 and -7 mgal. This map reflects the geometry of the Moho discontinuity, which deepens towards the SE. Figure 2C shows the distribution of the second order Bouguer anomalies. It is obtained by subtracting the first order-anomaly map of Fig. 2B from the total anomaly map of Fig. 2A. The anomalies linked with the Moho geometry thus disappear. Anomaly values range from -10 to $+7 \mathrm{mgal}$. Areas with negative values correspond to areas with densities lower than the mean 2.3 density. Inside the Forêt de Chaux area, the second-order Bouguer anomaly distribution is not homogeneous. However, a N70 E-trending elongated positive anomaly can be distinguished. It corresponds to the "heavy axis" detected by Devaux [1958]. The other positive domains correspond to the distribution areas of Paleozoic rocks (La Serre massif [Chauve et al., 
1983]) and Mesozoic formations (Jura belt). Figure 2D shows the vertical derivative of the secondorder Bouguer anomaly. It allows an accurate localization of the small-sized (local) anomalies. In particular, the $\mathrm{N} 70^{\circ}$ E-trending positive anomaly noticed on Figure $2 \mathrm{C}$ appears clearly.

\subsection{Seismic reflection and drilling data.}

The gravity anomaly described above was investigated in the late 1950s by seismic reflection and drilling along a profile oriented $\mathrm{N} 160^{\circ} \mathrm{E}$, that is perpendicular to the trend of the anomaly, and located at the western edge of the Forêt de Chaux area [Devaux, 1958]. The seismic profile revealed the presence of a north-verging asymmetric anticline folding upper Jurassic (Oxfordian and Kimmeridgian) limestones below the Forêt de Chaux deposits. The structure is characterized by a short northern limb and a long southern limb (Fig. 3). The interpretation of the seismic reflection profile also yielded a south-dipping reverse fault cutting the folded Jurassic strata. The $\mathrm{N} 70^{\circ} \mathrm{E}-$ trending axis of the anticline can be further constrained from borehole data [Devaux, 1958]. The seismic reflection results confirm that the positive gravity anomaly mentioned above corresponds to an anticline axis, at least in the western part of the Forêt de Chaux area. The anticline axis can be extrapolated eastward along the $\mathrm{N} 70^{\circ} \mathrm{E}$-trending positive gravity anomaly.

\section{Geomorphological constraints for a Pliocene to present-day deformation of the Forêt de Chaux area}

\subsection{Topography of the Forêt de Chaux area.}

The Forêt de Chaux depression is limited to the north and to the south by two main rivers, the Doubs and the Loue, both flowing towards the west and merging southwest of Dole (Fig. 4). Ground elevation along the course of these rivers decreases from $220 \mathrm{~m}$ for the Doubs or from 235 $\mathrm{m}$ for the Loue to $200 \mathrm{~m}$ at the confluence. In the Forêt de Chaux area, the mean slope of the Doubs river is $0.05 \%$, while it is $0.12 \%$ for the Loue river. The Forêt de Chaux surface between these two rivers morphologically consists of an alluvial abandonment surface incised by the Quaternary hydrographic network. Quaternary alluvial deposits, which are easily recognized by the presence of calcareous pebbles, are found only along the Doubs and Loue rivers and nowhere else. This indicates that the Forêt de Chaux surface is a unique monogenic surface. This surface is further characterized by a median ridge trending $\mathrm{N} 65^{\circ} \mathrm{E}$, dividing the Forêt de Chaux area in two catchment areas (Fig. 4). North of the median ridge, tributaries flow northward into the Doubs, while south of the crest line, they flow southwards into the Loue. Ground elevations along the median ridge are comprised between $240 \mathrm{~m}$ (western part) and $275 \mathrm{~m}$ (eastern part). It is important to note that the ridge runs parallel, and slightly to the north, of the trace of the anticline axis described above. In order to characterize the present-day morphology of the Forêt de Chaux area, seven elevation profiles have been drawn based on a 50m accuracy DEM (Fig. 5). Profiles 1 to 5 are perpendicular to the $\mathrm{N} 65^{\circ} \mathrm{E}$ ridge and profiles 6 and 7 are parallel to the ridge and located on either side of it.

At the time of the abandonment of the Forêt de Chaux alluvial surface, the slope of this surface was corresponding to the course of the Paleo Aar-Doubs and was thus oriented roughly NE-SW. The longitudinal profiles (ENE-WSW) show a regular mean topographic slope decreasing westwards with values comprised between 0.07 and $0.14 \%$ (Fig. 5). These topographic slope values are of the same order of magnitude as the mean slopes of the Doubs and Loue rivers and could correspond to the initial slope of the Forêt de Chaux abandonment surface. The transverse profiles (NNW-SSE) show mean topographic slopes dipping in opposite directions: the mean slopes of the areas located north of the $\mathrm{N} 65^{\circ} \mathrm{E}$ ridge dip northwards, while those of the areas located to the south of the ridge dip southwards. Where clearly defined, the junction between the two parts of the mean slope coincides with the median ridge. All the values of the mean slopes to the north of the $\mathrm{N} 65^{\circ} \mathrm{E}$ ridge are higher (by a factor comprised between 1.4 and 3.9) than those to the south of the ridge. 


\subsection{Drainage network organization within the Forêt de Chaux depression}

The drainage divide of the Doubs and Loue basins in the Forêt de Chaux is roughly formed by the median ridge (Fig. 4). On its left bank, the Doubs river shows a series of short second-order tributaries. South of the ridge, a composite network of second-order and third-order streams merges with the Loue river. In this area, the second-order tributaries, namely the Clauge, the Tanche and the Bief de la Lue, flow approximately E-W (Fig. 4). The distribution of third-order tributaries in this area is not symmetrical: quite extensive third-order streams are present on the right bank of the second-order tributaries, but lack or are very short on the left bank (Fig. 4). These third-order streams flow to the south whereas the second-order streams flows to the WSW (parallel to the Doubs and Loue river). This peculiar distribution suggests that the median ridge corresponds with the culmination of an differential uplift zone. The area south of the median ridge apparently experienced southward tilting while the area north of it was tilted in the opposite direction, that is northward. The third-order drainage network seems to have developed after the beginning of the tilting. The difference in length between the second-order tributaries of the Doubs and the secondorder and more specifically the third-order tributaries of the Loue could further reflect the asymmetry of the two uplifted flanks.

\subsection{Anomalies in the degree of incision of tributaries}

The asymmetry of the drainage network north and south of the median ridge is further confirmed by a difference in the degree of incision of second- and third-order tributaries. Transverse profiles drawn from the 1/25000 topographic map show that the second-order tributaries within the Forêt de Chaux depression located north of the median ridge are more incised than the third-order tributaries of the Clauge, the Tanche and the Bief de la Lue streams further south (Fig. 6). This qualitative difference in the degree of incision is quantitatively confirmed using the $\mathrm{V}_{\mathrm{f}}$ index defined as the ratio between valley floor width and valley height. The ratio is defined by the following formula [Bull, 1977, 1978]:

$$
\mathrm{V}_{\mathrm{f}}=2 \mathrm{~V}_{\mathrm{fw}} /\left[\left(\mathrm{E}_{\mathrm{ld}}-\mathrm{E}_{\mathrm{sc}}\right)+\left(\mathrm{E}_{\mathrm{rd}}-\mathrm{E}_{\mathrm{sc}}\right)\right]
$$

where $V_{f w}$ is the width of the valley floor, $E_{l d}$ and $E_{r d}$ the respective elevations of the left and right valley divides, and $E_{\mathrm{sc}}$ the elevation of the valley floor. The $\mathrm{V}_{\mathrm{f}}$ index indicates whether the stream is actively down cutting or is eroding laterally into the adjacent hillslopes. A small $\mathrm{V}_{\mathrm{f}}$ index corresponds to an incised valley. Within the Forêt de Chaux depression, the $\mathrm{V}_{\mathrm{f}}$ values of the Doubs tributaries are comprised between 0.38 and 1.0 while those of the Loue second-order and third-order tributaries are of the 2.67-4.14 range (Fig. 6).

The differences in incision intensity cannot be explained by differences in bedrock erodibility since all investigated streams flow on the same poorly to moderately consolidated alluvial conglomerates. Indeed, the lower gravel and the upper gravel complexes show a comparable degree of erodibility, as revealed by examination of exposures of the two types of deposits. Neither can the differences in the degree of incision be accounted for by differences in the size of the catchment areas on either side of the crest line. All concerned streams have catchment areas of about the same order of size (5 $\sim 10 \mathrm{~km}^{2}$ ). A likely explanation for the observed incision pattern could be a difference in local base levels which are formed by the Doubs and Loue to the north and south respectively. The Doubs is marked by a generally more incised hydrographic network. However, the main parameter driving the local incision of the investigated tributary streams is the difference of elevation between the watershed interfluves and the basin outlet. In the present case, this difference in elevation is almost similar between all the studied basins (Fig. 6). We therefore assume that the observed difference in incision intensity between the northern and the southern parts of the Forêt de Chaux is due to differential uplift along the median ridge that caused a steepening of the northern part of the Forêt de Chaux area with respect to the southern part. 


\subsection{Opposite lateral migrations of the Doubs and Loue rivers in the Forêt de Chaux depression}

The Doubs and Loue are presently meandering rivers. Mapping of abandoned meanders still recognizable on aerial photographs or ancient topographic maps shows that the present-day channel of the Doubs is consistently located north of its abandoned meanders whereas the Loue river predominantly flows to the south of its abandoned meanders (Fig. 4). Concerning the Loue, 37 on a total of 52 abandoned meanders $(71 \%)$ are found to the north of the present course. Concerning the Doubs, 11 out of 13 (85\%) abandoned meanders are located to the south of the present course. These observations suggest a lateral northward shift of the Doubs and, by contrast, a lateral southward shift of the Loue at least since the establishment of the meandering dynamics of the two rivers. The age of the setting-up of the meandering regime will be discussed below. The northward shift of the Doubs is further supported by the presence of pronounced limestone cliffs on the northern (or right) bank of the river, while no cliff can be observed on the southern (or left) bank, despite a southward gentle dip of the bedding plane of the limestone. This hypothesis is further strengthened by an examination of the drainage pattern of the tributaries of the Doubs and Loue rivers in the Forêt de Chaux area.

Two different processes may have caused the diverging lateral channel migration of the Doubs and Loue rivers. River migrations may be the result of Pleistocene erosion of the Forêt de Chaux alluvial surface which would have led to the input of large quantities of detrital sediments into the drainage basins of the Doubs and Loue rivers. However, there is no field evidence for a such a process. There are no alluvial or colluvial fans on the rims of the Doubs and Loue valleys and, for both rivers, only few tributaries large enough to transport significant amounts of detrital sediments currently flow from the Forêt de Chaux surface. This is particularly true for the Loue river (the most meandering river) which shows only one third-order tributary able to provide enough sedimentary material to cause a meander migration. The second possible cause, which is the most plausible, is an uplift along the median ridge which would cause a northward tilting of the gravel surface located to the north and associated northward migration of the Doubs river, and a southward tilting of the gravel surface located to the south and associated southward migration of the Loue river.

\section{Discussion}

\subsection{Interpretation of the Forêt de Chaux sub-surface geology and indications for recent deformation of the alluvial series}

The thickness of the Pliocene alluvial deposits in the Forêt de Chaux area is highly changeable. According to drilling results, it is comprised between 30 to $120 \mathrm{~m}$ [Devaux, 1958]. This variability in thickness was recently confirmed by vertical electrical soundings [Molliex, 2005]. The thickness variations were interpreted by Kerrien et al. [1979] as reflecting the presence of Plio-Quaternary grabens beneath the Forêt de Chaux area. However, this interpretation does not take into account the seismic profiles obtained earlier [Devaux, 1958] and is unable to explain the $\mathrm{N}^{\circ} 0^{\circ} \mathrm{E}$ gravity anomaly. Moreover, it also lacks structural observations which could have supported a PlioQuaternary extensional tectonic activity. Another interpretation based on the Messinian salinity crisis (MSC), which pre-dates the deposition of the Forêt de Chaux gravels, can account for the abrupt Pliocene deposit thickness variations. Indeed, the geometry of the Pliocene alluvial deposits can be influenced by pre-depositional erosion-controlled topography. The MSC caused a strong incision of the Mediterranean continental margin and resulted in the regressive incision of the Rhône valley. Near Lyon, in the southern part of the Bresse Graben, incision reached more than 200 m [Clauzon et al., 1973; Clauzon, 1982 ; Clauzon et al., 1995]. The uppermost fill of the Bresse Graben is mainly composed of incompetent marls that are easy to incise along its entire length [e.g. Petit et al., 1996]. It is hence possible that the MSC-related incision propagated further northward into the Forêt de Chaux area, resulting in a highly irregular topography that was later filled up. 
According to drilling data [Devaux, 1958], silty and sandy deposits often constitute the base of the alluvial fill, suggesting an ingression of the Bresse lake within paleo-valleys before the deposition of the lower gravels. Moreover, the repartition of the high-thickness anomalies zones is not consistent with the local tectonic features under the forêt de Chaux $\left(\mathrm{N} 70^{\circ} \mathrm{E}\right.$ anticline or $\mathrm{N} 20^{\circ} \mathrm{E}$ normal faults of Dole area) [Molliex, 2005].

There is an apparent spatial correlation between the buried $\mathrm{N} 70^{\circ} \mathrm{E}$-trending anticline revealed by geophysical and drilling data and the $\mathrm{N} 65^{\circ}$ E-trending topographic ridge that divides the Forêt de Chaux depression into two different geomorphological domains. A post-Pliocene propagation of the anticline hidden beneath the Pliocene deposits could possibly account for the morphological and drainage anomalies observed in the Forêt de Chaux area. It would in particular explain the apparent basement uplift of the $\mathrm{N} 65^{\circ} \mathrm{E}$ ridge indicated by opposite shifts of the Doubs and Loue rivers, asymmetrical drainage pattern and different incision intensity of tributary streams.

\subsection{Estimates of the age of the deformation in the Forêt de Chaux area.}

According to the geomorphological observations outlined above the surface of the Forêt de Chaux gravels has apparently been affected by tectonic deformation. Hence, the upper chronological boundary for this tectonic activity is given by the biostratigraphically constrained deposition age of the gravels (4.2-2.6 Ma; Petit et al. 1996; Fejfar et al., 1998). Tectonic deformation has been active until or even later than the establishment of the meandering channels of the Doubs and Loue rivers (Fig. 4), as is suggested by their lateral migration. Throughout the northwestern Alpine foreland, the alluvial fill of most river valleys (including the Doubs and Loue rivers) typically consist of lower coarse high-energy gravels deposited by high energy, braided, torrential rivers, overlain by upper fine, silty or sandy sediments deposited by low-energy alluvial meandering rivers [Berger et al, 2008; Séara et al., 2002; Vannière et al., 2003]. The high-energy deposits date back to the upper Peniglacial or Late-glacial epoch, that is before 10000 years BP, while the postglacial low-energy deposits are younger than 10000 years BP and often constitute the present-day active flood plain [Berger et al, 2008; Séara et al., 2002; Vannière et al., 2003]. It follows that the opposite migrations of the meandering Doubs and Loue rivers occurred after the Peniglacial period, that is after 10000 years BP.

\subsection{Lateral continuation and structural interpretation of the Forêt de Chaux Anticline}

The lateral continuation of the hidden anticline of the Forêt de Chaux is difficult to be traced. Towards the southwest, it disappears beneath the thick deposits of the Bresse Graben. To the northeast, it could connect to the Routelle anticline (Fig. 1). The Routelle anticline itself vanishes further east by progressive decrease of the interlimb angle. No evidence for active deformation has so far been recognized along the Routelle anticline. Further northeast, a late Quaternary activity has recently been demonstrated along the Citadelle anticline at Besançon [Madritsch et al., 2010b]. Like the Forêt de Chaux anticline, the Citadelle anticline also folds middle and upper Jurassic limestones and marls [Dreyfuss \& Kuntz, 1967]. The growth of the Citadelle anticline continued pro parte after the deposition of Forêt de Chaux-like fluviatile conglomerates now found at about $110 \mathrm{~m}$ above their original position inferred by extrapolation from an equilibrium profile between the Sundgau region of the southern Rhine graben and the Forêt de Chaux [Dreyfuss \& Glangeaud, 1950; Campy, 1984; Madritsch et al., 2010b]. Uplifted Holocene alluvial deposits lying above the Citadelle anticline axis show that the growth of this anticline is still underway [Madritsch et al., 2010b]. However, given the distance and the lack of continuous exposures between the Forêt de Chaux anticline and the Citadelle anticline, it is hazardous to link the two anticlines. Nevertheless, the two folds can have been propagating during the Quaternary in response to the same stress field.

\subsection{Structural style of active deformation and implications for seismic hazard assessment}


The apparent active fold growth along the northern rim of the Jura fold-and-thrust belt requires a dicussion on the possible causes of this deformation. Two end-member scenarios are currently being discussed for the present day tectonic scenario of the northern Alpine foreland [Meyer et al., 1994; Madritsch et al., 2008; Schmid \& Slejko, 2009]. Following the pioneering work of Laubscher [1961], the first end-member case considers that the deformation leading to the formation of the Jura fold-and-thrust belt is restricted to the sedimentary cover above the decollement horizons located within Middle to Upper Triassic evaporites. The Paleozoic basement underneath the decollement presumably remained unaffected by tectonic deformation caused by stresses of remote origin (overthrusting of the Alpine external crystalline massifs). In this scenario, the active deformation remains shallow $(<1$ or $2 \mathrm{~km})$ and is presumably aseismic. Such a thin-skinned tectonics scenario has been retained by Nivière \& Winter [2000] to account for the recent folding in the southern Upper Rhine Graben area.

The second tectonic end-member scenario invokes a deformation of both the sedimentary cover and the Paleozoic basement beneath it. In such a thick-skinned tectonics scenario, shortening in the sedimentary cover accommodated by folding and imbricate thrusting is supposed to be synchronous with fault formation or reactivation in the underlying crystalline basement. Fault activity in the basement takes place at depths larger than 1 to $2 \mathrm{~km}$ and down to $15 \mathrm{~km}$ or deeper. At such depths, the high confining stresses can allow large strain accumulation and hence seismic faulting. Late Paleozoic steeply dipping faults $\left(\sim 60^{\circ}\right)$ are known to exist in the crystalline basement beneath the Jura belt [e.g., Rocher et al., 2003; Rotstein \& Schaming 2004; Ustazweski et al., 2005; Madritsch et al., 2008]. Similar basement faults are also exposed in the northeastern Massif Central (Morvan area) where they strike N60 E. Meyer et al. [1994] proposed that the 1356 Basel earthquake (supposed magnitude $6 \sim 6.8$ ) was the consequence of the reactivation of such a N60 ${ }^{\circ}$-trending basement fault. The same scenario was invoked for the 2004 Besançon earthquake (ML 5.1) whose focal depth was about $15 \mathrm{~km}$ [Charmoille et al., 2005].

Several observations suggest that the Forêt de Chaux anticline may be related to basement fault reactivation. Firstly, the fold is located clearly outside of the known Jura fold-and-thrust belt domain (Fig. 1). Secondly, the direction of the anticline axis is oblique to the front of the Jura belt and to structures inside it (Fig. 1). This is particularly obvious to the west of the Forêt de Chaux area where the Jura structures (folds and faults of the so-called Quingey faisceau [Bonte \& Celet, 1975]) strike N-S, that is in high obliquity to the $\mathrm{N}^{\circ} 5^{\circ}$ to $\mathrm{N} 70^{\circ} \mathrm{E}$ trend of the Forêt de Chaux anticline axis. Thirdly, this fold axis orientation is parallel to the strike of basement faults mapped or imaged in this area (Madritsch et al., 2008). It is interesting to note that the Routelle anticline mentionned above is also related to a basement normal fault (Fig. 1).

\section{Conclusion}

The analysis of the morphology of the Forêt de Chaux depression and of the geometry of the associated hydrographic system indicates that the abandoned Pliocene alluvial surface is deformed. This deformation, which likely started after 2.4 Ma has probably continued beyond $10000 \mathrm{BP}$. Geophysical and borehole data indicate that the deformation could be accounted for by the propagation of an anticline that affects the upper Jurassic limestone layers but is so far hidden beneath the Pliocene deposits. Quaternary folding in the vicinity of the Jura front is not a new observation but, unlike evidence for Quaternary deformation from other areas, the one described in the Forêt de Chaux area appears to be related with deep-seated basement fault reactivation. This may have implications on the assessment of the seismic hazard of the area.

\section{Acknowledgements}

We thank Marc Cushing and Michel Sébrier for their helpful reviews. Discussions in the field with Jean-Pierre Mettetal (DIREN Besançon), Stefan Schmid (Basel University) and Michel Campy (Bourgogne University) were very helpful. Vincent Godard (CEREGE) is thanked for his help in 
gravity data processing.

\section{References}

Berger, J.F., Salvador, P.-G., Franc, O., Verot-Bourrely, A., Bravard, J.P. (2008). - La chronologie fluviale postglaciaire du haut couloir rhodanien. Cahiers de Paléoenvironnement, Collection EDYTEM, 6, 117-143.

Bonte A. \& Celet P. (1975). - Carte géologique de la France à 1/50000. Feuille Quingey. - BRGM Editions.

Bonvalot J. (1974). - Les cailloutis de la Forêt de Chaux (Jura): leurs rapports avec les matériaux détritiques du Sundgau et du nord de la Bresse. Thesis, University of Dijon, $89 \mathrm{p}$.

Bull W. (1977). - Tectonic morphology of the Mojave Desert. U.S. Geol. Surv. Contact Rep. 14-08001-G-394, Office of earthquakes, Volcanoes and Engineering, Menlo Park, Calif., 188 p.

Bull W. (1978). - Tectonic morphology activity classes of the south front of the San Gabriel Mountains, California. U.S. Geol. Surv. Contact Rep. 14-08-001-G-394, Office of earthquakes, Volcanoes and Engineering, Menlo Park, Calif., 59 p.

Calais E. (1999). - Continuous GPS measurements across the Western Alps, 1996-1998. Geophys. J. Int., 138, 221-223.

Calais E., Galisson L., Stéphan J.F., Delteil J., Deverchère J., Larroque C., Mercier de Lépinay B., Popoff M. \& Sosson M. (2000). - Crustal strain in the Southern Alps, France, 1948-1998. - Tectonophysics, 319, 1, 1-17.

Campy M. (1984). - Signification dynamique et climatique des formations et terrasses fluviatiles dans un environnement de moyenne montagne. - Bull. Assoc. Fr. pour l'Etude du Quaternaire, 1-2-3, 87-92.

Campy M. \& Contini D. (1981). - La néotectonique en Franche-Comté (France), Vosges méridionales - Jura septentrional. - Bull. Assoc. Fr. Pour l'Etude du Quaternaire, 193-205.

Chaline J. (1984). - La séquence des rongeurs de Bresse en tant que référence biostratigraphique et paléoclimatique. - Géologie de la France, 3, 251-258.

Chauve P., Campy M., Pernin C. \& Morre-Biot N. (1983). - Carte géologique de la France à 1/50000. Feuille Pesmes. - BRGM Editions.

Chauve P., Kerrien Y., Pernin C., Cornet J. \& Féraud, J. (1979). - Notice explicative de la carte de Dole au 1/50000. - BRGM Editions, 32 p.

Charmoille, A., Fabbri, O., Mudry, J., Guglielmi, Y. \& Bertrand, C. (2005). - Post-seismic permeability change in a shallow fractured aquifer following a ML 5.1 earthquake (Fourbanne karst aquifer, Jura outermost thrust unit, eastern France). -

Geophysical Research Letters, 32, L18404, DOI:10.1029/2005GL023582.

Chateauneuf J.J. \& Farjanel G. (1989). - Synthèse géologique des bassins permiens français. Mém. BRGM, 128, 288 p.

Clauzon G. (1973). - The eustatic hypothesis and the pre-Pliocene cutting of the Rhône Valley. Deep Sea Drill Project, Initial report, Washington, 13, part. 2, 1251-1256.

Clauzon G. (1982). - Le canyon messinien du Rhône: une preuve décisive du « dessicated deep basin model » (Hsü, Cita et Ryan, 1973). - Bull. Soc. Géol. Fr., 24, 231-246.

Clauzon G., Rubino J.L. \& Savoye B. (1995). - Marine Pliocene Gilbert-type fan deltas along the French Mediterranean coast. - IAS 16th Regional Meeting of Sedimentology. Field trip Guide Book. Publication ASF, 23, 145-222.

Debrand-Passard S., Courbouleix S. \& Lienhart M.J. (1984). - Synthèse géologique du Sud-Est de la France. - Mém. BRGM, 125-126, 615 pp.

DeMets C., Gordon R.G., Argus D.F. \& Stein S. (1990). - Current plate motions. Geophys. J. Int., 101, 425-478.

Devaux J. (1958). - Rapport de fin de campagne core-drills sur la structure de Rahon-Villette-lesDole. - Unpublished report downloadable at the Banque de Données du Sous-Sol, 
http://infoterre.brgm.fr/, $35 \mathrm{p}$.

Dreyfuss M. \& Glangeaud L. (1950). - La vallée du Doubs et l'évolution morphotectonique de la région bisontine. - Ann. Sci. Univ. Besançon, 5, 2.

Dreyfuss M. \& Kuntz G. (1967). - Carte géologique de la France à 1/50000. Feuille Besançon. BRGM Editions.

Ervin P.C. (1977). - Theory of the Bouguer anomaly. - Geophysics, 42, 1468.

Farjanel G. (1985). - La flore et le climat du Néogène et du Pléistocène de Bresse (France) d'après l'analyse pollinique. Implications chronostratigraphiques. Doc BRGM, Orléans, no 97,202 p.

Fejfar O., Heinrich W.D. \& Lindsay, E.H. (1998). - Updating the Neogene rodent biochronology in Europe. 6 Mededel. Nederl. Inst. Toegepaste Geowetensch. TNO 60, 533-554.

Formento-Trigilio M.L., Burbank D.W., Nicol A., Shulmeister J. \& Rieser U. (2002). - River response to an active fold-and-thrust belt in a convergent margin setting, North Island, New Zealand. - Geomorphology, 49, 125-152.

Giamboni M., Ustaszewski K., Schmid S.M., Schumacher M.E. \& Wetzel A. (2004a). - PlioPleistocene transpressional reactivation of Paleozoic and Paleogene structures in the Rhine-Bresse transform zone (Northern Switzerland and eastern France). Geol. Rund., online first, doi:10.1007/s00531-003-0375-2.

Giamboni M., Wetzel A., Nivière B. \& Schumacher M. (2004b). - Plio-Pleistocene folding in the southern Rhinegraben recorded by the evolution of the drainage network (Sundgau area; northwestern Switzerland and France). - Eclogae Geol. Helvetiae, 97, 17-31. DOI 10.1007/s00015-004-1112-4.

Giamboni M., Schneider B. \& Wetzel A. (2004). - Geomorphic response of alluvium rivers to active tectonics: Examples from the southern Rhine Graben, Austrian Journal of Earth Sciences, 97, 24-37.

Grandjean G., Ménnechet C., Debéglia N. \& Bonijoly D. (1998). - Insuring the quality of gravity data. - EOS Trans. American Geophysical Union, 79, 217-221.

Jackson J., Norris, R. \& Youngson J. (1996). - The structural evolution of active fault and fold systems in central Otago, New Zealand: evidence revealed by drainage patterns. Journal of Structural Geology, 18, 217-234.

Kerrien Y., Chauve P. \& Pernin C. (1979). - Carte géologique de la France à 1/50000. Feuille Dole. - BRGM Editions.

Laubscher H. (1961). - Die Fernschub hypothese der Jurafaltung. - Eclogae Geol. Helv., 54, 222282.

Liniger H. (1967). - Pliozän und Tektonik des Juragebirges. - Eclogae Geol. Helv., 60, 2, 407-490.

Madritsch H., Schmid S.M. \& Fabbri, O. (2008) Interactions between thin- and thick-skinned tectonics along the north-western front of the Jura fold-and-thrust belt. Tectonics, 27, TC5005 doi:10.1029/2008TC002282

Madritsch H., Fabbri O., Hagedorn E.M., Preusser F., Schmid S.M. \& Ziegler P.A. (2010a). Feedback between erosion and active deformation: Geomorphic constraints from the north-western Jura fold-and-thrust belt. Int. Journal of Earth Sciences (Geol. Rundschau). 99, Supplement 1, 103-123.

Madritsch H., Preusser F., Fabbri O., Bichet V., Schlunegger F. \& Schmid S. (2010b). - Late Quaternary folding in the Jura Mountains: evidence from syn-erosional deformation of fluvial meanders. Terra Nova, 22, 147-154.

Meyer B., Lacassin R., Brulhet J. \& Mouroux B. (1994). - The Basel 1356 earthquake: which fault produced it ? - Terra Nova, 6, 1, 54-63.

Molliex S. (2005). - Evolution morphotectonique récente du contact Jura-Bresse. Impact sur les propriétés aquifères du cône alluvial de la forêt de Chaux. Unpublished Master thesis. University of Franche-Comte, $35 \mathrm{p}$.

Nivière B. \& Winter T. (2000). - Pleistocene northwards fold propagation of the Jura within the southern Upper Rhine Graben. - Global and Planetary Change, 27, 263-288. 
Petit C., Campy M., Chaline J. \& Bonvalot J. (1996). - Major paleohydrographic changes in Alpine foreland during the Plio-Pleistocene. - Boreas, 25, 131-143.

Puisségur J.J. (1984). - Les faunes malacologiques de la Bresse. Significations écologiques, climatiques et chronologiques. - Géologie de la France, 3, 281-302.

Rocher M., Chevalier, F., Petit C. \& Guiraud M. (2003). - Tectonics of the Northern Bresse region (France) during the Alpine cycle. - Geodynamica Acta, 16, 131-147.

Rotstein, Y. \& Schaming, M. (2004). Seismic reflection evidence for thick-skinned tectonics in the northern Jura. Terra Nova, 16, 250-256.

Schumm S.A., Dumont J.F. \& Holbrook J.M. (2000). - Active tectonics and alluvial rivers. Cambridge University Press, 276 p.

Séara, F., Rotillon, S. \& Cupillard, C. (2002). - Campements mésolithiques en Bresse jurassienne. Choisey et Ruffey-sur-Seille (Jura). Documents d'Archéologie Française, 92, 344 p.

Schmid, S.M. \& Slejko, D. (2009). - Seismic source characterization of the Alpine foreland in the context of a probabilistic seismic hazard analysis by PEGASOS Expert Group 1 (EG1a). Swiss Journal of Geosciences, 102, 121-148.

Ustaszewski K. \& Schmid S.M.. (2007). - Late Pliocene to recent thick-skinned tectonics at the Upper Rhine Graben - Jura Mountains junction. - Swiss J. Geosci., 100, 293-312.

Vannière B., Bossuet G., Walter-Simonnet A.V., Gauthier E., Barral P, Petit C., Buatier M. \& Daubigney A. (2003). - Land use change, soil erosion and alluvial dynamic in the lower Doubs Valley over the 1st millenium AD (Neublans, Jura, France). Journ. Archaeol. Sci., 30, 1283-1299.

Figure captions

Fig. 1. Simplified geological map of the study area showing the Pliocene Forêt de Chaux depression, the inferred Forêt de Chaux anticline, and the Routelle (R) and Citadelle (C) anticlines (modified after Dreyfuss \& Kuntz, 1967, Bonte \& Celet, 1975, Kerrien et al., 1979, and Chauve et al., 1983).

Fig. 1. Carte géologique simplifiée du secteur d'étude montrant la dépression pliocène de la Forêt de Chaux, l'anticlinal supposé de la Forêt de Chaux, et les anticlinaux de Routelle (R) et de la Citadelle (C) (modifiée d'après Dreyfuss \& Kuntz, 1967, Bonte \& Celet, 1975, Kerrien et al., 1979, et Chauve et al., 1983).

Fig. 2. Bouguer anomaly maps for the Forêt de Chaux area. A: total Bouguer anomaly (computed for a mean crustal rock density of 2.3); B: first-order Bouguer anomaly distribution; C: secondorder Bouguer anomaly distribution; D: second-order Bouguer anomaly vertical derivative.

Fig. 2. Carte d'anomalies de Bouguer du secteur de la Forêt de Chaux. A: anomalie de Bouguer totale (calculée avec une densité moyenne des roches crustales égale à 2.3); B: distribution des anomalies de Bouguer de premier ordre; $\mathrm{C}$ : distribution des anomalies de Bouguer de second ordre; D: dérivée verticale des anomalies de Bouguer de second ordre.

Fig. 3. Interpretative N-S cross-section of the Villette-les-Dole hidden anticline based on seismic reflection profiles and drilling data (modified after Devaux, 1958). The location of the cross-section is indicated on the Figure 2D.

Fig. 3. Coupe géologique interprétative N-S à travers l'anticlinal de Villette-les-Dole déduite de profils de sismique réflexion et de données de forages (modifié d'après Devaux, 1958). La localisation de la coupe est indiquée sur la Figure 2D. 
Fig. 4. Digital Elevation Map of the Forêt de Chaux depression and surroundings. The location of the seismic lines and drillings carried out in the 1950s is also indicated.

Fig. 4. Modèle numérique de terrain de la dépression de la Forêt de Chaux et des environs. La localisation des profils sismiques et des forages réalisés dans les années 1950 est également indiquée.

Fig. 5. Elevation profiles across the Forêt de Chaux area obtained on the basis of the $50 \mathrm{~m}$ accuracy digital elevation model (DEM). The values of the mean slopes are in percent.

Fig. 5. Profils topographiques à travers la Forêt de Chaux obtenus à partir de modèles numériques de terrain de $50 \mathrm{~m}$ de précision. La valeur des pentes moyennes est en pour-cent.

Fig. 6. Topographic profiles perpendicular to tributaries of the Doubs and Loue showing the various degrees of incision.

Fig. 6. Profils topographiques perpendiculaires aux affluents du Doubs et de la Loue montrant les différents degrés d'incision. 


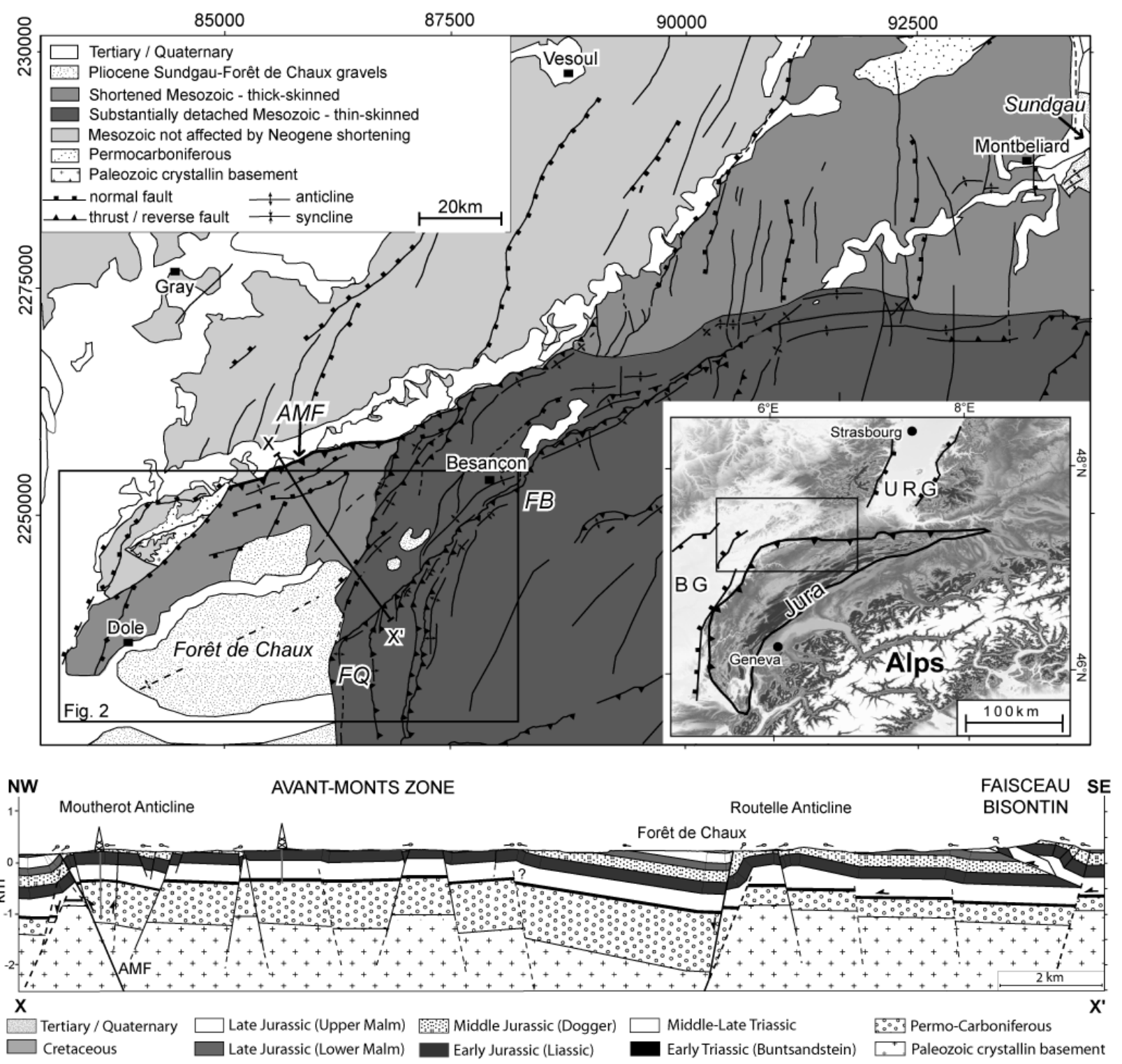

Figure 1 

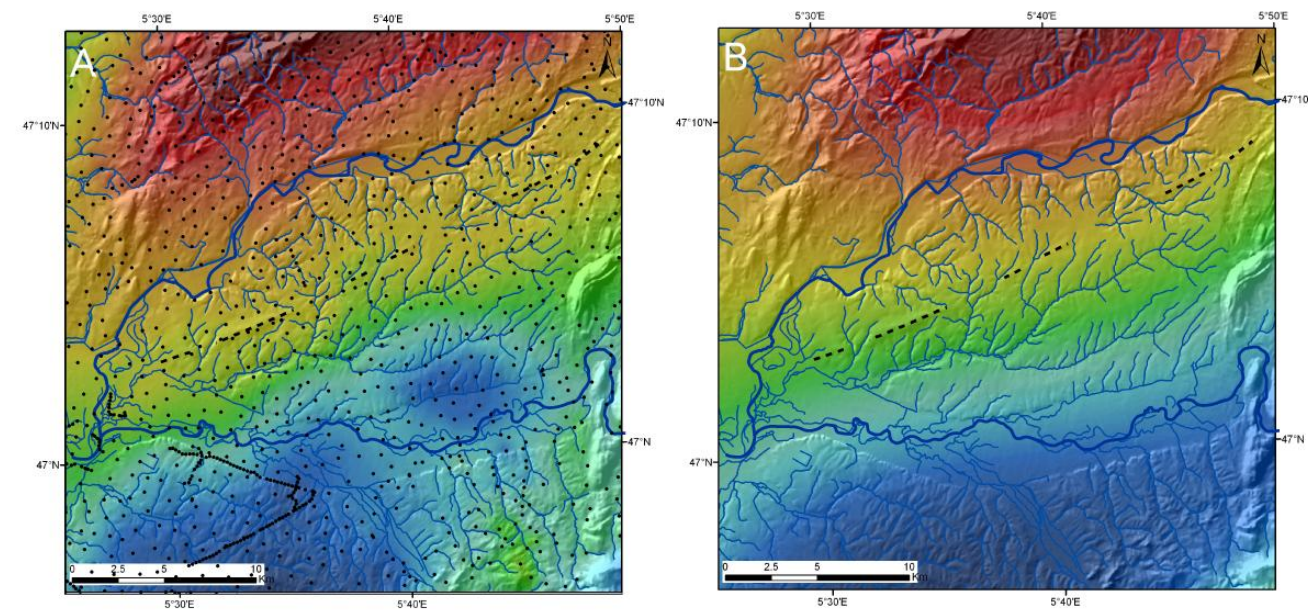

Hydrographic network

- - - Morphologic anomaly

- Gravity station

- Deep boreholes near Villette-les-Dole

A B Geological cross-section of Fig. 3

A) Bouguer anomaly (mgal)
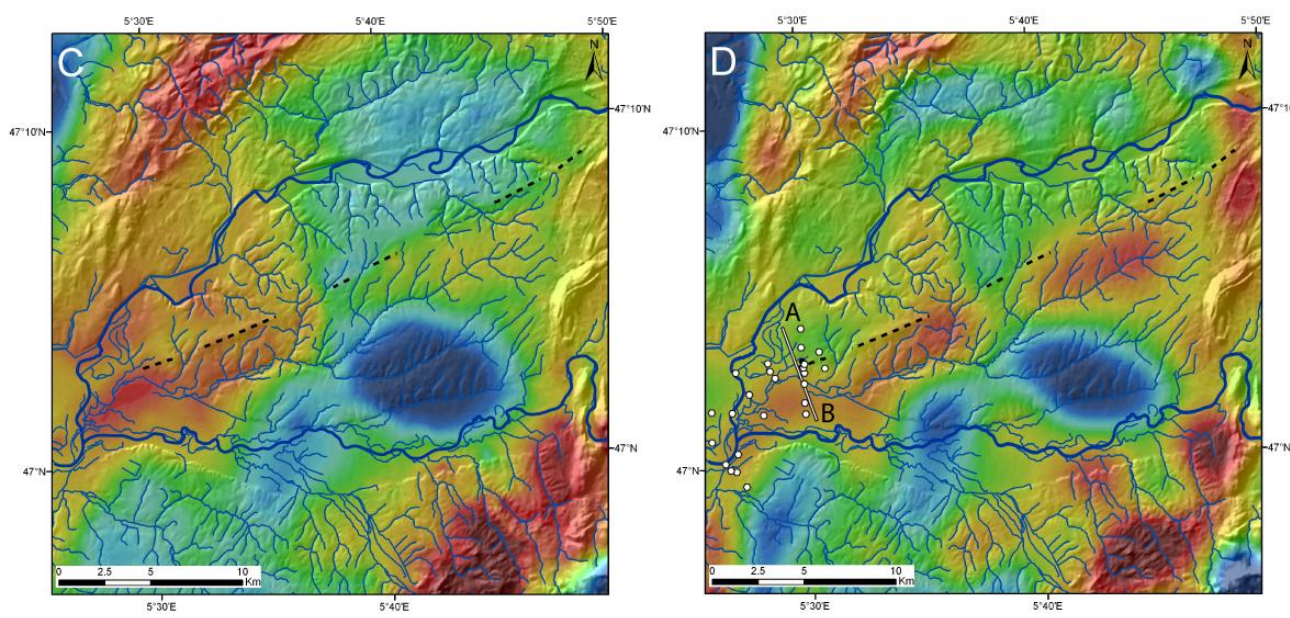

$-4.836$

$-31.0618$

B) $1^{\circ}$

$-7.02418$

$-28.7623$

C) Residual Bouguer anomaly (mgal)

785219

$-10.9287$

D) Vertical gradient of

Residual Bouguer anomaly

(mgal.m)

0.003707

Figure 2 


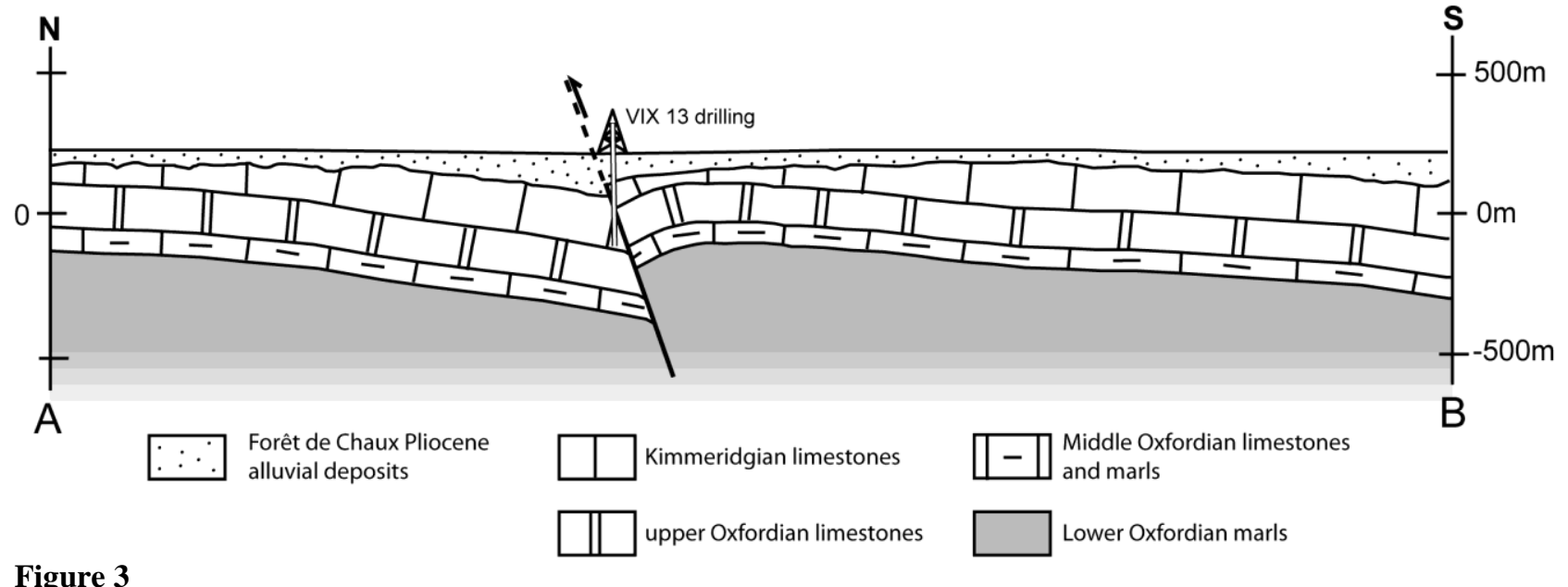

Figure 3 


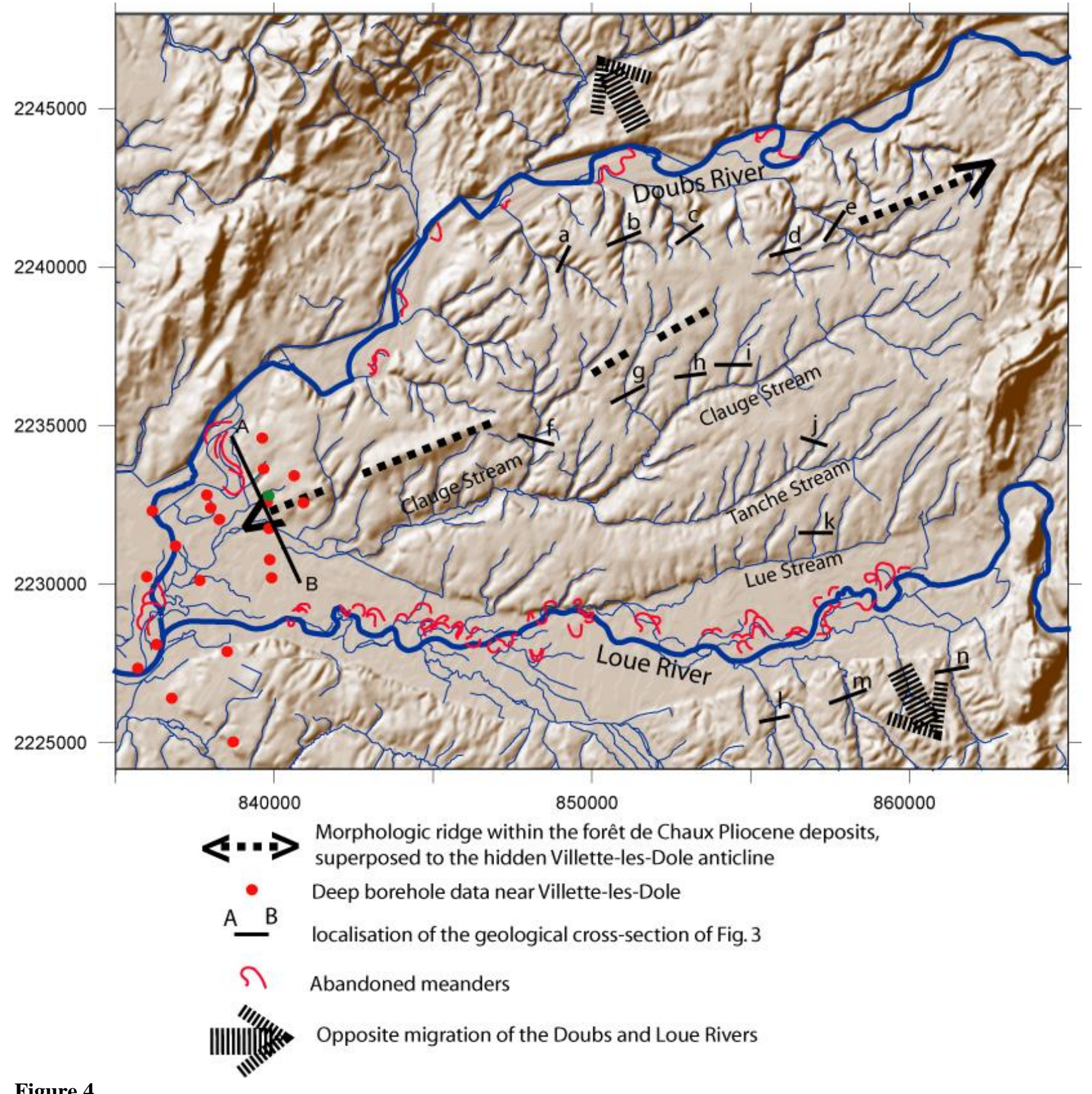

Figure 4 

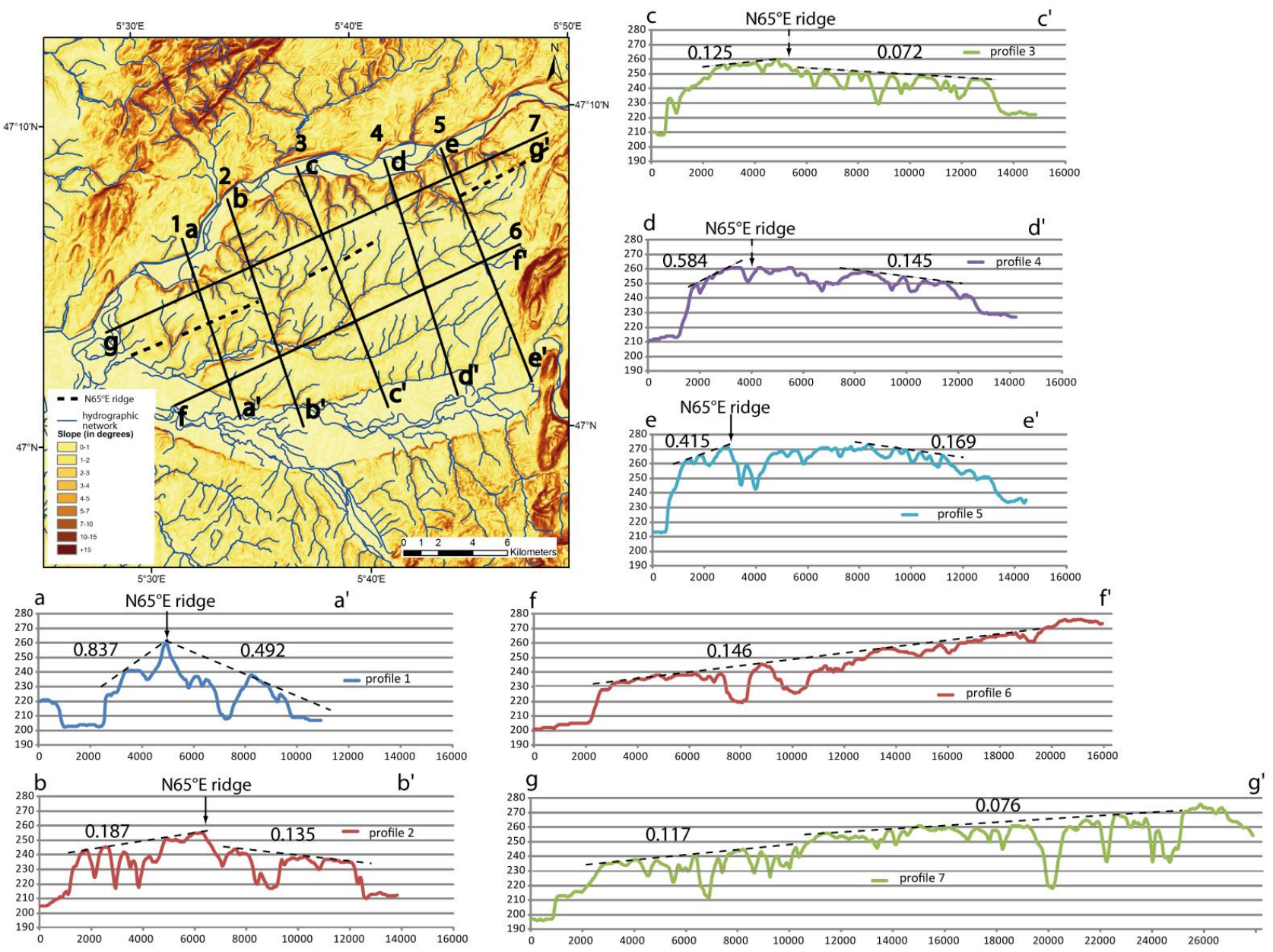

Figure 5 


\section{1- North of the forêt de Chaux}

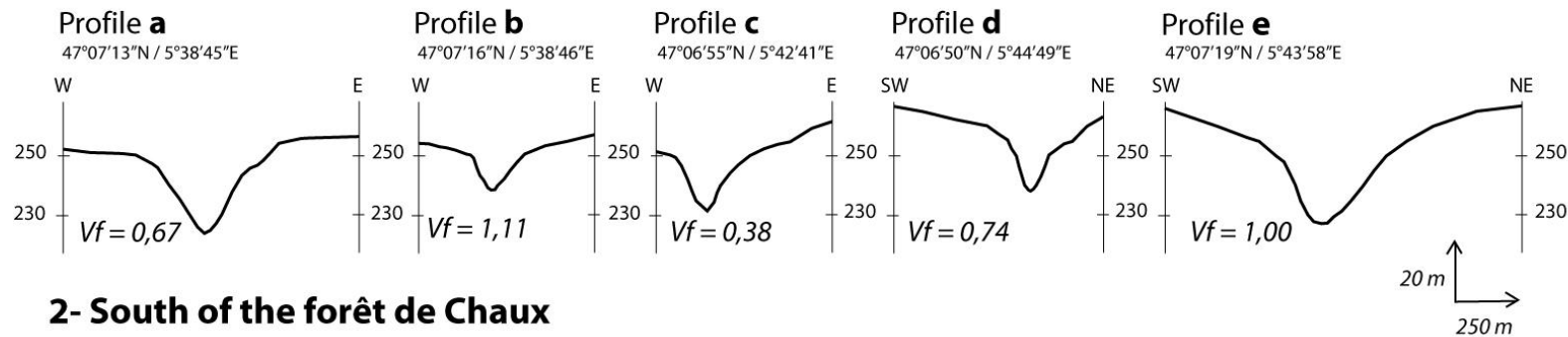

$$
\begin{array}{lll}
\text { Profile } \mathbf{f} & \text { Profile } \mathbf{g} & \text { Profile } \mathbf{h} \\
47^{\circ} 04^{\prime} 27^{\prime \prime} \mathrm{N} / 5^{\circ} 38^{\prime} 36^{\prime \prime} \mathrm{E} & 47^{\circ} 04^{\prime} 47^{\prime \prime} \mathrm{N} / 5^{\circ} 42^{\prime} 12^{\prime \prime} \mathrm{E} & 47^{\circ} 04^{\prime} 20^{\prime \prime} \mathrm{N} / 5^{\circ} 40^{\prime} 01^{\prime \prime} \mathrm{E}
\end{array}
$$

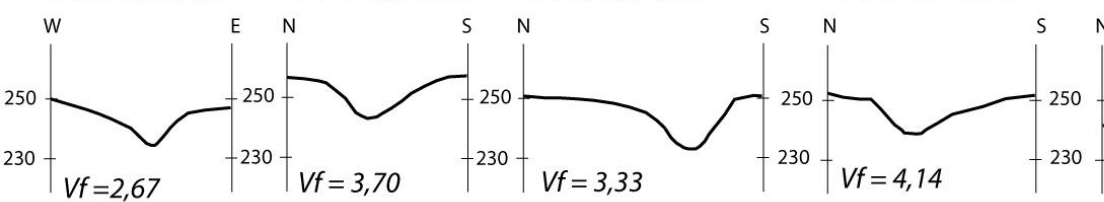

Profile j

$47^{\circ} 02^{\prime} 21^{\prime \prime} \mathrm{N} / 5^{\circ} 39^{\prime} 44^{\prime \prime} \mathrm{E}$

\section{3- South of the Loue river}
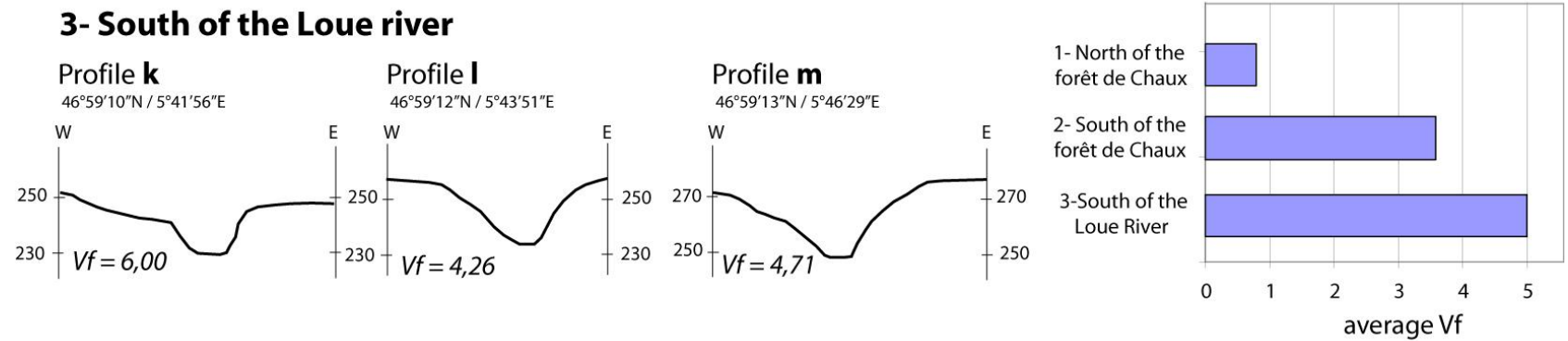

Figure 6 